\title{
TERRAM and LUX Series: Four Yellow-fleshed and Three White- fleshed Peaches
}

Carolina Font i Forcada, Gemma Reig, and Christian Fontich

Institute of Agrifood Research and Technology, Fruitcentre, Lleida, Spain

Ignasi Batlle

Institute of Agrifood Research and Technology, Mas Bové, Tarragona, Spain

Simó Alegre

Institute of Agrifood Research and Technology, Fruitcentre, Lleida, Spain

Celia M. Cantín

Institute of Agrifood Research and Technology, Fruitcentre, Lleida, Spain; and Aragonese Agency for Research and Development Foundation (ARAID), Zaragoza, Spain; and Center for Research and Agrifood Technology of Aragon (CITA), Zaragoza, Spain

\section{Iban Eduardo}

Institute of Agrifood Research and Technology, Fruitcentre, Lleida, Spain; and Center for Research in Agricultural Genomics (CRAG)-Superior Council of Scientific Investigations (CSIC)-Institute of Agrifood Research and Technology (IRTA)-Autonomous University of Barcelona (UAB)-University of Barcelona (UB), Campus UAB, Barcelona, Spain

\section{Joaquim Carbó \\ Institute of Agrifood Research and Technology, Mas Badia, Girona, Spain}

Arsène Maillard and Laurence Maillard

Agro Séléctions Fruits (ASF), La Prade de Mousseillous, Elne, France

\section{Joan Bonany}

Institute of Agrifood Research and Technology, Mas Badia, Girona, Spain

Additional index words. color, fruit quality, maturity, production, Prunus persica

In Spain, peach [Prunus persica (L.) Batsch] production has experienced an increase of $\approx 30 \%$ during the past 20 years [Ministry of Agriculture, Food and Environment (MAPAMA), 2021]. In 2018, the total peach cultivated surface area was $\approx 50,000$ ha, with the majority of peach production located in Ebro Valley, northeastern Spain. Aragon and Catalonia are the two most

Received for publication 30 Mar. 2021. Accepted for publication 11 June 2021.

Published online 20 August 2021.

This research was supported by the Research Centers of Catalonia (CERCA) Program/Generalitat of Catalonia. We also thank FruitFutur (Spain) for their support to the breeding program and FruitFutur members for their help during the whole trialing process carried out at Gimenells. C.F.F. and G.R. contributed equally.

C.F.F. is the corresponding author. E-mail: carolina.font@irta.cat.

This is an open access article distributed under the CC BY-NC-ND license (https://creativecommons. org/licenses/by-nc-nd/4.0/). important Spanish peach regions within Ebro Valley, producing $\approx 430,000$ and 409,000 tons annually, respectively (MAPAMA, 2021). Spain is the leading European peach producer and the world's largest exporter, with a crop value of almost USD 1 billion.

The varietal renovation carried out in Spain in the last 20 years is unique worldwide. Spain started its own scion breeding program about 12 years ago to gain access to novelties, to reduce cost of royalties, and to guarantee adaptation to local growing conditions. With the goal of developing high-quality cultivars welladapted to the locally hot climate, the Catalan peach industry in 2004 initiated the joint Agro Séléctions Fruits (ASF)-Institute of Agrifood Research and Technology (IRTA) breeding program located at Gimenells, Lleida, a major center of peach production in Spain (Batlle et al., 2012; Cantín et al., 2017). The objective of the ASF-IRTA scion peach breeding program was to develop new cultivars adapted to chilling areas between zones with 1000 and 1500 chill units or between 42 and 75 chill portions and warm conditions similar to the Mediterranean area $\left(32^{\circ} \mathrm{C}\right.$ mean summer daily system and 300-400 $\mathrm{mm}$ annual rainfall) and to have high-quality fruit both at harvest and after cold storage, with the ultimate goal of satisfying consumers. As a result of this collaborative effort, the ASF-IRTA scion peach breeding program has released the TERRAM and LUX series of yellow- and white-fleshed peaches, respectively.

These seven new peach cultivars produce attractive, colored fruits with yellow or white flesh. The yellow-fleshed TERRAM peaches include several cultivars with a balanced or acidic flavor, and a more recently developed range of cultivars with sweet taste, good firmness, barely any hairiness on the epidermis, and a high level of skin coloration (Font i Forcada et al., 2013, 2019; Reig et al., 2015). With the LUX series, the harvesting calendar is progressively completed, with cultivars of high coloration, sweet taste, good pulp consistency, aptitude for handling, and good production. This progressively greater coloration represents an important change with respect to the traditional bicolor cultivars, with less coloration, and a balanced and aromatic flavor. TERRAM and LUX peach cultivars will supply high-quality, firm, attractive fruit over 9 weeks, from early July until midSeptember, in the medium chilling zone of Ebro Valley and other production regions with similar climatic conditions.

\section{Origin}

Regarding TERRAM peaches, 'TERRAM 2902' was a seedling from EP 01.27.83.97 $\mathrm{Pj} \times$ ASF 01.07.33.01 Nj, 'TERRAM 3401' was from ASF 02.04.55.02 $\mathrm{Pj} \times 58 \mathrm{GC76}$, 'TERRAM 3601' was from 'Ryan Sun' $x$ open pollination, and 'TERRAM 3701' was from ASF 01.06.39.99 $\mathrm{Pj} \times$ ASF 01.07.33.01 $\mathrm{Nj}$. For LUX peaches, 'LUX 2902' was a seedling from ASF 02.04.32.02 $\mathrm{Pj} \times \mathrm{ASF}$ 02.10.66.02 Nb, 'LUX 3502' was from ASF 03.13.07.04 $\mathrm{Pb} \times$ open pollination, and ' $\mathrm{LUX}$ 3501 ' was from ASF 01.05.05.98 $\mathrm{Pb} \times \mathrm{ASF}$ 01.24.93.02 Nj.

\section{Description}

Phenotypic and morphologic descriptors (tree, flower, leaf, and fruit traits) developed by the International Union for the Protection of New Varieties and Plants (UPOV, 2010) and the Community Plant Variety Office (CPVO, 2015) were used to describe TERRAM and LUX peach series (Supplemental Table 1).

TERRAM series peach (yellow-fleshed) are moderately vigorous, except 'TERRAM 3601', which is less vigorous and has spreading habit similar to 'TERRAM 2902'. Full bloom occurs during March, and harvesting dates are between July and September (Table 1).

LUX series peach (white-fleshed) are moderately vigorous and have spreading habit. Full bloom occurs during March, and harvesting dates are between July and September (Table 1). 
Table 1. Comparison of several characteristics of the TERRAM and LUX peach series with the commercial standard 'Sweet Dream' and 'Summer Sweet' trialed at the Institute of Agrifood Research and Technology, Spain.

\begin{tabular}{|c|c|c|c|c|c|c|c|c|c|}
\hline Trait & $\begin{array}{c}\text { TERRAM } \\
2902\end{array}$ & $\begin{array}{l}\text { TERRAM } \\
3401\end{array}$ & $\begin{array}{c}\text { TERRAM } \\
3601\end{array}$ & $\begin{array}{c}\text { TERRAM } \\
3701\end{array}$ & LUX 2902 & LUX 3501 & LUX 3502 & $\begin{array}{l}\text { Sweet } \\
\text { Dream }^{z}\end{array}$ & $\begin{array}{l}\text { Summer } \\
\text { Sweet }^{\mathrm{z}}\end{array}$ \\
\hline Flowering period & 7-16 Mar. & 9-20 Mar. & 11-23 Mar. & 10-19 Mar. & 8-15 Mar. & 11-21 Mar. & 10-21 Mar. & 4-25 Mar. & 5-22 Mar. \\
\hline Harvest period & 7-28 July & 13-17 Aug. & $\begin{array}{l}31 \text { Aug.-- } \\
15 \text { Sept. }\end{array}$ & 7-27 Sept. & 10-31 July & $\begin{array}{l}26 \text { Aug.- } \\
6 \text { Sept. }\end{array}$ & $\begin{array}{l}22 \text { Aug.- } \\
9 \text { Sept. }\end{array}$ & $\begin{array}{l}23 \text { July- } \\
14 \text { Aug. }\end{array}$ & $\begin{array}{l}27 \text { June- } \\
19 \text { July }\end{array}$ \\
\hline Yield (kg/tree) & 67.7 & 73.6 & 64.5 & 58.5 & 73.9 & 71.7 & 87.8 & 62.0 & 32.0 \\
\hline Flesh firmness $(\mathrm{N})$ & 53.9 & 51.7 & 59.8 & 54.9 & 52.9 & 61.7 & 57.8 & 40.9 & 46.7 \\
\hline Soluble solids ( ${ }^{\circ}$ Brix) & 10.8 & 11.3 & 11.6 & 11.3 & 10.5 & 11.7 & 11.1 & 10.5 & 14.8 \\
\hline $\begin{array}{l}\text { Acidity }\left(\mathrm{g} \cdot \mathrm{L}^{-1} \text { malic }\right. \\
\text { aid) }\end{array}$ & 4.4 & 3.3 & 2.4 & 3.9 & 3.8 & 3.0 & 2.6 & 3.5 & 2.7 \\
\hline Red blush (\%) & $80-100$ & $70-90$ & $70-80$ & $30-60$ & $90-100$ & $80-90$ & $80-100$ & $90-100$ & $90-95$ \\
\hline Dominant caliber (mm) & $75-80$ & $80-85$ & $80-85$ & $75-80$ & $75-80$ & $80-85$ & $75-80$ & $>85$ & $75-80$ \\
\hline
\end{tabular}

For both peach series, there is no need for thinning at full bloom, as fruit thinning will effectively optimize fruit size.

\section{Performance}

All seven cultivars were originally selected as seedlings grown at selection plots, and then grafted onto 'Cadaman' rootstock after selection, being the fifth most used rootstock in the Ebro Valley's (Reig et al., 2013). Trees of each selection were placed in an experimental orchard belonging to the Institute of Agrifood Research and Technology (IRTA)-Fruitcentre, located in Gimenells, northeastern Spain (lat. $41^{\circ} 39^{\prime} 18.77^{\prime \prime} \mathrm{N}$, long. $0^{\circ} 23^{\prime} 31.41^{\prime \prime} \mathrm{E}$; elevation, $230 \mathrm{~m}$ ). The trees were trained to an open or Catalan vase system (Iglesias, 2019) and were spaced at $5 \times 3 \mathrm{~m}$. Each year, the trees received integrated pest management. The quantitative data summarize the average values for 9 years collected on full-size trees.

Maturity time. 'TERRAM 2902' and 'LUX 2902' are midseason cultivars, whereas the other three TERRAM and other two LUX cultivars are considered late-season cultivars (Table 1). Their fruit development periods (FDP) is noted in Supplemental Table 1.

Yield. The trees were harvested at two to three picks separated by 3 to $5 \mathrm{~d}$, except 'LUX 2902' and 'LUX 3502', which - with adequate field management - can be harvested in only one or two picks. After harvesting, the entire production of each controlled tree was graded for fruit size and weight using a commercial electronic fruit grader (MAF RODA, Iberica, Spain). Under our conditions, all seven peach cultivars stood out for their high productivity and good fruit size, regardless of their harvest season (Table 1).

Fruit quality. Fruits of all seven cultivars were examined at commercial maturity using samples of 12 fruits per cultivar. All the cultivars were generally found to be sweeter than current commercial cultivars within the same harvest period, juicier, more aromatic, and firm (Table 1, Supplemental Table 1). All the fruit evaluated had red skin color covered greater than 95\% except for 'TERRAM 3701', which is bicolored, with a rounded shape. The releases generally had rounded pistil tip except for 'LUX 3501' (Supplemental Fig. 1).

Postharvest performance. Thirty fruits from the first harvest of each cultivar were kept at $0.5^{\circ} \mathrm{C}$ for $30 \mathrm{~d}$, followed by $2 \mathrm{~d}$ at $20^{\circ} \mathrm{C}$. Each fruit was scored based on visual rating of chilling injury symptoms (mealiness and internal browning). Each cultivar was classified as having a good, moderate, or poor long-term performance. The whitefleshed peaches 'LUX 2902' and 'LUX 3501 ' were the least susceptible to chilling injury after long periods of cold storage (Supplemental Table 1).

\section{Availability}

The cultivars are protected by the Community Plant Varieties Office with the following registration numbers: 20132986 for 'TERRAM 2902', 20132982 for 'TERRAM 3401', 20113176 for 'TERRAM 3601', 20132981 for 'TERRAM 3701', 29132983 for 'LUX 2902', 20113181 for 'LUX 3501', and 20122742 for 'LUX 3502'.

Virus-free plants are available from nurseries authorized by the Institute of Agrifood Research and Technology (IRTA, Spain). The plant material was laboratory-tested and showed negative results for Agrobacterium tumefaciens [via reverse transcription-polymerase chain reaction (RT-PCR)], Apple chlorotic leaf spot virus [via enzyme-linked immunosorbent assay (ELISA)], Candidatus Phytoplasma prunorum (via RT-PCR), Peach latent mosaic viroid (via molecular hybridization), Plum pox virus (via ELISA), Prune dwarf virus (via ELISA), Prunus Necrotic ring spot virus (via ELISA), Xanthomonas arboricola pv. pruni (via RT-PCR), and Xylella fastidiosa (via RT-PCR).

\section{Literature Cited}

Batlle, I., C. Fontich, L. Lozano, I. Iglesias, G. Reig, S. Alegre, G. Echeverría, F. de Herralde, E. Claveria, R. Dolcet-Sanjuan, J. Carbó, J. Bonany, A. Maillard, and L. Maillard. 2012. The peach breeding programme IRTA-ASF: Aiming for high fruit quality. Acta Hort. 940:75-78, doi: 10.17660/ActaHortic.2012.940.8.

Cantín, C., C. Fontich, I. Batlle, I. Iglesias, R. Dolcet-Sanjuan, S. Alegre, J. Carbó, J. Bonany, A. Maillard, and L. Maillard. 2017. The joint IRTA-ASF peach breeding program: Outstanding quality fruit adapted to the Mediterranean conditions. Acta Hort. 1172:151-154, doi: 10.17660/ActaHortic.2017.1172.29.

Community Plant Variety Office. 2015. Protocol for tests on distinctness, uniformity and stability. TP/053/2 Rev.

Font i Forcada, C., Y. Gogorcena, and M.A. Moreno. 2013. Fruit sugar profile and antioxidants of peach and nectarine cultivars on almond $\times$ peach hybrid rootstocks. Scientia Hort. 164:563-572, doi: 10.1016/j.scienta.2013.10.020.

Font i Forcada, C., G. Reig, R. Giménez, P. Mignard, L. Mestre, and M.A. Moreno. 2019. Sugars and organic acids profile and antioxidant compounds of nectarine fruits influenced by different rootstocks. Scientia Hort. 248:145-153, doi: 10.1016/j.scienta.2018.12.010.

Iglesias, I. 2019. Sistemas de plantación 2D: Una novedad en almendro, una realidad en frutales: Hacia una alta eficiencia. Rev. Frutic. 67:23-44.

International Union for the Protection of New Varieties of Plants. 2010. Guidelines for the conduct of tests for distinctness, uniformity and stability to peach [Prunus persica (L.) Batsch]. TG/53/7 Rev. International Union for the Protection of New Varieties of Plants, Geneva, Switzerland. 21 June 2021. <https://www. upov.int/edocs/tgdocs/en/tg053.pdf $>$.

Ministry of Agriculture, Food and Environment (MAPAMA). 2021. Mar. 2021. <https://www. mapama.gob.es/es/>.

Reig, G., S. Alegre, F. Gatius, and I. Iglesias. 2013. Agronomical performance under Mediterranean climatic conditions among peach [Prunus persica (L.) Batsch] cultivars originated from different breeding programmes. Scientia Hort. 150:267-277, doi: 10.1016/ j.scienta.2012.11.006.

Reig, G., S. Alegre, F. Gatius, and I. Iglesias. 2015. Adaptability of peach cultivars [Prunus persica (L.) Batsch] to the climatic conditions of the Ebro Valley, with special focus on fruit quality. Scientia Hort. 190:149-160, doi: 10.1016/j.scienta.2015.04.019. 

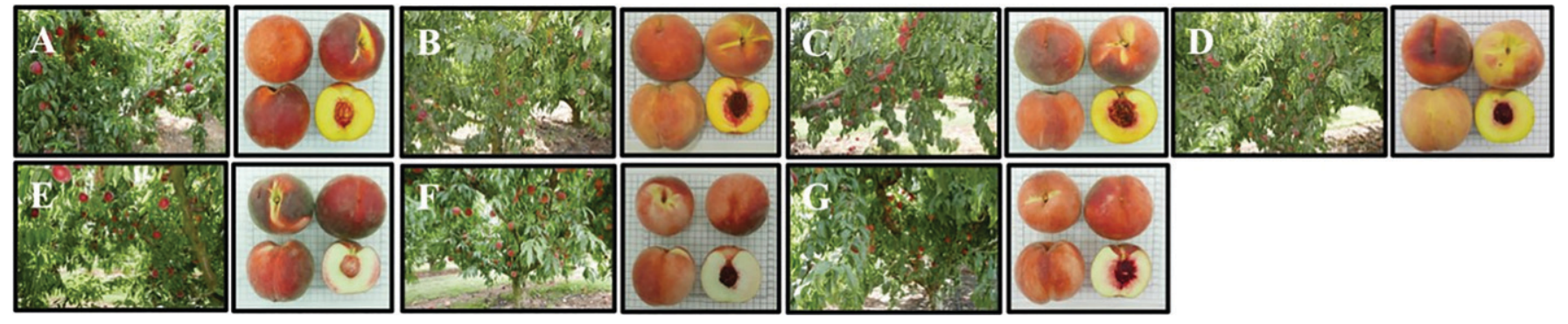

Supplemental Fig. 1. Typical fruit appearance of commercially ripe TERRAM and LUX peach series: (A) 'TERRAM 2902', (B) 'TERRAM 3401', (C) 'TERRAM 3601', (D) 'TERRAM 3701', (E) ‘LUX 2902', (F) 'LUX 3501', and (G) 'LUX 3502'.

Supplemental Table 1. Comparison of several characteristics of the TERRAM and LUX peach series trialed at the Institute of Agrifood Research and Technology, Gimenells, Lleida, Spain.

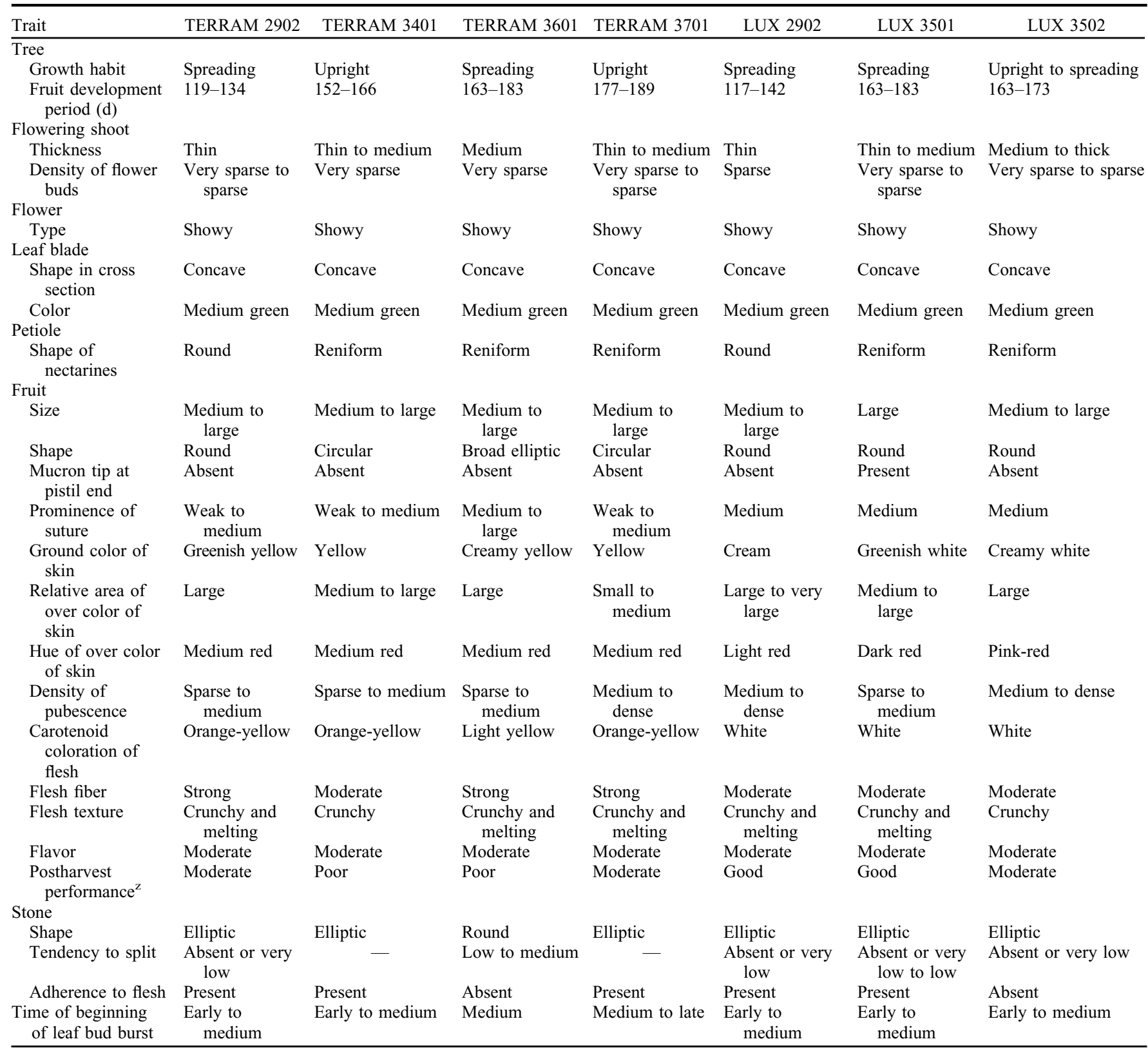

${ }^{\bar{z}}$ Good long performance, $<25 \%$ of total fruits had mealiness and/or internal browning symptoms; moderate, $25 \%$ to $50 \%$ of total fruits had mealiness and/or internal browning symptoms; and poor, $>50 \%$ of total fruits had mealiness and/or internal browning symptoms. 